\title{
MARKET COMPETITION IN TELEVISION INDUSTRY IN INDONESIA (CASE STUDY: KOMPAS SPORT IN KOMPAS TV)
}

\author{
Ebnu Yufriadi ${ }^{*}$, Mungky Diana Sari ${ }^{1}$, and Benedicta Gita Adinda Satyaningtyas ${ }^{1}$ \\ ${ }^{1}$ Mass Communication Program, Communication Department, Faculty of Economics and Communication, Bina \\ Nusantara University, Jakarta, Indonesia 11480 \\ *ebnu@binus.ac.id
}

\begin{abstract}
This study about media economy wants to see how far the relationship between the market and the content strategy of a television program. Kompas Sport program of Kompas TV is selected to be the focus of this study, because the program as a sport program is not only presenting game shows, but also other side of athletes' life. This program is considered interesting because it is packaged in contrast to other sport programs. This study uses critical theories regarding media economics, market oligopoly, market structure, market conduct, and market performance. While the method that is chosen in this study is qualitative with critical paradigm. The result of this research is showing that there is relationship between market competition and content strategy. It showed that there is interdependence between market structure condition the company itself. The company's behavior in the interdependent oligopoly market led to mergers and acquisitions of several television stations.
\end{abstract}

Keywords: media economy, market oligopoly, market structure, market conduct and market performance

\section{INTRODUCTION}

The development of visual media today is so rapid, including television. Television as a mainstream media tries to meet the needs of market information in the form of program impressions, both in the form of entertainment and news. Various ways are done to meet the needs of the community, from packaging an interesting program, to educational content. But unfortunately, the programs are now no longer determined solely by the TV in question, but rather from the desire of the market.

The other unique side of TV is the functionality in dual product market. Where the TV is facing two different markets. In one TV product, it has to deal with two markets that impact on the program's impressions. The first market is in the form of an event program that is measured by an audience rating. Audience rating is the thing that comes from the individual audience used to consume television programs. While the second market is the sales program and audience rating to the advertising agency. There are two types of television stations. First, public television that contains a variety of topics, ranging from entertainment, movies and news. While the second is television news or news channel, the television that the percentage of broadcast programs greater to the news, can reach $70-80 \%$. This study will specially discussed about the dynamics that occur in the national news station television programs in terms of content strategy in media market competition.

The presence of Metro TV and TvOne after being a news channel is arguably a breath of fresh air for Indonesian television dominated by soap operas and other television melodramas. The persistence of Metro TV and TvOne to awaken the Indonesian nation from its long sleep is paid off. As news television, Metro TV and TvOne become the 'up-to-date' and accurate news guidelines for the people of Indonesia.

Kompas TV as a newcomer realizes that differentiation has become one of the keys to success in competing as one of the newcomers among its rivals in the national broadcasting TV industry. The motto "Independen Terpercaya" was installed as a tagline that strengthens its positioning statement. Moreover, Metro TV and TvOne can not be released its image of affiliation with certain politics. Metro 
TV is owned by Surya Paloh who is also the Chairman of National Democrat (Nasdem), while TvOne belongs to Aburizal Bakrie, former Chairman of Golkar Party.

As a newcomer, Kompas TV tries to position itself different from its competitors. Previously national private TV stations polarized in two poles, one side that is more oriented to the load of entertainment events and the other side that is more oriented on the news show. For news broadcasts, Metro TV and TvOne are slightly hostage with its ownership position. Kompas TV tries to use this advantage, as an independent and reliable television according to its slogan. Then enter the Kompas TV with news broadcasts but using an independent presentation of impartial or compromised agenda setting of a particular political choice. The audience is given new options or options related to the latest information sources from news television in Indonesia.

\section{Background of research}

In the sales program and audience rating, it will affect the advertisers to benefit from the audience by using media content. So, the higher the audience's need for media content, the higher the media put up the price of the advertisement.

For that, the TV stations are now starting to race to create interesting content to attract market interest. One of the things that is done is to create a content strategy in the face of the wants and needs of the market. Therefore, in determining the content strategy required support sales division, promotion, and human resources. According to Kotler dan Keller (2016) there are four things needed to meet the needs of the market, which are product, price, place and promotion. Although Indonesia, with an oligopoly market structure type, where the resulting product has homogeneous tendencies but still allows for different, market conditions, will certainly greatly affect the conduct and performance of the media.

Based on the Nielsen on 2011, table data on advertising revenue obtained by television stations over the past few years, the market structure of the national private commercial television business in Indonesia can be classified into oligopoly market types. The oligopoly market type is manifested in the presence of some major player television stations that lead the market, in which none controls the price, but the actions of one party affect the other and the market price. So, the resulting product can still have a chance to be homogeneous or different.

The impact of oligopoly market type on the planning of national private commercial television program, is the development of market follower strategy. The essence of this strategy is to imitate the product "market leader", in this case the program that managed to get the highest rating. This is what causes the tendency of homogeneous television programs on different television stations. Various programs presented by various national private television stations, whether the soap operas, comedy, and various other television shows actually have a tendency "similar but not the same". Title may vary, actor may switch, but story format, story logic, plot, characterizations and story settings remain similar. It is difficult to say to determine a local television program in Indonesia that really shows new and innovative things. Even if there are, it is counted very few or only a handful. So that the various entertainment shows up to journalistic impressions even appearing in the national private television stations in Indonesia today show the same and similar face.

The tendency of these homogeneous television programs is indirectly driven by mergers and acquisitions that occur between several television stations in Indonesia, which also means the accumulation of capital, interests and power. However, the main purpose of mergers and acquisitions is the strategy undertaken by the media to deal with the relatively small increase in national advertising budgets, with the number of stations getting more and more segmented. So by merging, the media is able to build new strengths when faced with industry changes with increasingly thick grouping. In Indonesia, the merger and acquisition strategy was spearheaded by RCTI, TPI (now MNC TV) and Global TV into the MNC (Media Nusantara Citra) group, followed by TV7 which later changed its name to Trans 7 after Trans TV acquired into Trans Corp, and Lativi which later became TvOne and ANTV, most of which were owned by Bakrie Group. These mergers and acquisitions have resulted in the television business competition map changing completely and immediately affecting the content of the media incorporated therein.

Meanwhile, the network television also began to compete. It is presented to replace television station that once owned by Kompas Gramedia, that is TV7. Since the shares of TV7 were purchased by Trans Corp which stood under Chairul Tanjung's leadership in 2006 and TV7's name was changed to 
Trans7, Kompas Gramedia's share of Trans7 declined to almost half from Trans Corp. On September 11, 2011, Kompas TV changed its logo by removing the words "TV" on the logo, and the text "TV" was re-used from 5 October 2012 until now. On October 19, 2017, Kompas TV changed its logo by removing the " $\mathrm{K}$ " icon on the logo. On January 28, 2016, Kompas TV focused on being a news channel in the Indonesian Voice event. On October 19, 2017, Kompas TV changed its logo and slogan to "Independen | Terpercaya", to coincide with the event Rosi Special: Launching Rumah Pilkada 2018.

\section{THEORETICAL FRAMEWORK}

\section{Media Economic Theory}

This study refers to Media Economic Theory, which describe economics as the study of how people use limited resources to produce commodities of value and distribute in different groups. So the media economy can be translated as a study that examines how the media industry uses limited resources to produce content programs distributed to consumers in society to satisfy various wants and needs. Media economic studies help understand the economic relationship between media production and the public, the advertisers and the public at large (Albarran, 2010).

Media as a party that provides information to the audience, would require a market to market their business. The meaning of market according to Albarran (2010) is the meeting place between the seller and the buyer. The market includes some sellers who provide the same product or service to the same consumer group.

In the dual media market, the first market is television products in the form of event programs whose measurements can be made using a rating audience. The use of television media products requires individual time from the audience. In the second market, television media companies are dealing directly with the advertising market. The advertiser seeks access to the audience that matches the television program being used. These two markets are affecting each other. The higher the demand or interest in the event program, then the media company may charge the advertiser a higher price. Mc Connell and Bruce (2003) argue that Structure - Conduct - Performance (SCP) analysis provides a guide for empirically formulating assessments of the implementation of the media market.

\section{Market Structure and Market Conduct}

Market structure analysis focuses on the market structure of the television industry. There are five elements of market structure that include the number of sellers and buyers, market integration, product differentiation, barriers and cost structure. Buyers and sellers explain market concentration, the analysis is focused on the degree of monopoly that occurs on the market through an overview of the actors engaged in the television business along with the description of the competitive conditions that occur.

In media economic studies, market concentration can be measured by two events. First, by measuring market percentage based on circulation and rating data. Secondly, by calculating the percentage of earnings controlled by the top companies. Market integration in the market structure consists of vertical and horizontal integration. Vertical integration illustrates the success of collaboration or cooperation of several industries, such as cooperation between production houses with cinema or advertising agencies with newspaper companies. While horizontal integration occurs when some similar media combine into a container. Product differentiation describes the variety or variety of media produced products.

\section{Oligopoly}

One form of industrial organization is oligopoly. According to Luis M.B. Cabral (2017), the market structure in general can be classified into two parts, namely monopoly and perfect competition. Carbal divides the oligopoly market into two forms; the Bertrand model and the Cournot model, both of which show the process of dependence among strategic decisions made among competing firms in the oligopoly market.

The Bertrand model is defined as a competitive model that relies on pricing as a key strategy in competition. The demand for goods against the company, in the perspective of the Bertrand model, depends heavily on pricing made by a competitor. 


\section{METHOD}

Qualitative approach is used in this research because it can open social phenomenon in television industry in Indonesia. The observation is done through personal in-depth interviews about content strategy conducted by market participants in the competition of television business with oligopoly market structure type in Indonesia. And it would be even better to let subjects express their responses as freely and truthfully as possible.

While the case study involves qualitative research that focuses on one or more cases within a limited time span. The advantage is that case studies usually produce the best theory (Bungin. 2011). Qualitative data used by researchers can come from two sources: field research or field research and historical-comparative research or historical-based comparative research. The triangulation research was conducted in a comparative-historical way and combined with a field research system for researching important aspects of an era of social life (past programs) or on different cultures combined with field research and through interviews with competent practitioners in their fields.

\section{RESULT AND DISCUSSION}

\section{Profile of Kompas TV}

Kompas TV is a media company that presents inspirational and entertaining television content for Indonesian families. In accordance with the vision of the mission carried, Kompas TV package news, adventure \& knowledge, and entertainment programs that puts the quality. (About Kompas TV)

The content of Kompas TV programs are news program that is firm, directional, and hopeful. In addition, for other programs, Kompas TV emphasizes the exploration of Indonesia, both natural wealth, cultural treasures, Indonesia now, until the talent of achievement. Not only stop at the television programming, film production is also available on the big screen with interesting story stories and supported talents of talented art of Indonesia. (Vision of TV Compass Mission)

Kompas TV is a private television established by Kompas Gramedia, named PT Gramedia Media Nusantara. However, in its development until now, Kompas TV is owned by two big companies namely PT Gramedia Media Nusantara (GMN) and PT Cipta Megaswara Televisi (CMT). In 2016 the official TV Compass confirms its existence as a news television station and converts its slogan into "Berita dan Inspirasi Indonesia".

The program that became the object of this research is Kompas Sport. Kompas Sport is a news program that contains reviews of events from the world of sports both nationally or internationally, not only about the game, but also the passion, lifestyle and knick-knacks that are certainly associated with sports. Kompas Sport is present every night at $23.00 \mathrm{pm}$ to increase knowledge to the general public about the world of sports. Packaged not only based on oral exposure and Visual Tape (VT) but accompanied by graphics, diagrams, or other makes Kompas Sport is far from the boring word. Kompas Sport, more relaxed and sporty style, provides up-to-date information on matches and news from all sports for a week, More thematic and more participatory showers and exposes by practicing sports or hobbies taken. Here is the structure of the Department of Sport in charge of sports programs in Kompas $\mathrm{TV}$, whether bulletin, magazine and sports production.

\section{Discussion}

The discussion in this study begins with an analysis of the market structure of the television industry in Indonesia today. The focus of research is directed to comparing the five elements of market structure faced by Kompas TV which include: number of sellers / buyers, product differentiation, barriers to entry, cost structures and vertical integration. The position of the five elements in the research is to see the effect on the market conduct and performance of both TV stations.

\section{Numbers of Sellers/Buyers}

This analysis focuses on the degree of monopoly that occurs on the market through the depiction of the actors or entrepreneurs who plunge into the television business along with the description of the competitive conditions that occur, through the seller and the buyer. Measurements can be seen from the concentration of the industry market in two ways. First, measure the market percentage based on rating and share data. Second, by calculating the percentage of ad revenue. In Indonesia, the second 
measurement of market concentration of television industry is held by Television Audience Measurement Nielsen.

Nielsen is trusted today by the majority of TV stations as a research institution on rating and share. This is because the implementation of the methodology refers to the Global Guidelines for TV Audience Measurement (Global Guidelines for TV Audience Measurement). The methodology is based on standard Nielsen rating measurement procedures in the world. Measurements were then conducted in ten major cities, namely Jakarta, Bogor, Tangerang, Bekasi, Depok, Bandung, Semarang, Yogyakarta, Surabaya, Denpasar, Makassar, Medan, Palembang and Banjarmasin. Distribution of samples vary by city. The number difference is based on the population of television ownership in each city.

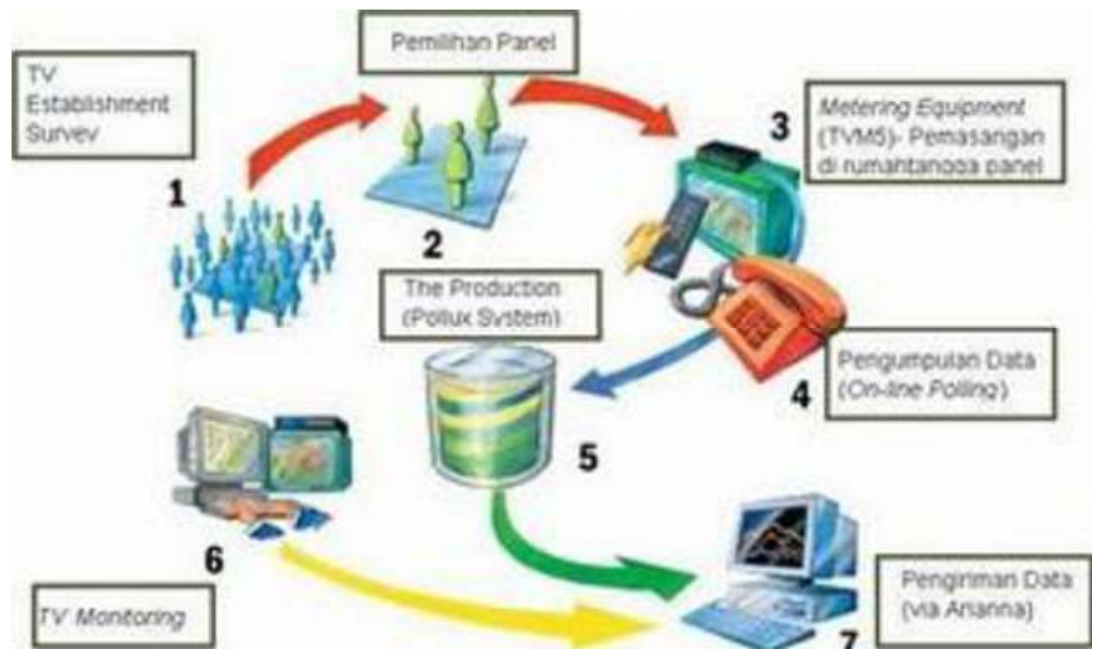

Figure 1. Standard procedure of Nielsen Audience Measurement Survey (source: Nielsen, 2011)

From the explanation above, it shows that Kompas Sport as one of the programs owned by Kompas TV has the data rating and share as follows:

Table 1. Performance of Kompas Sport Program in the Last 3 Months Period

\begin{tabular}{|c|c|c|}
\hline \multirow{2}{*}{ ISO Week } & Date & KOMPAS SPORT NIGHT \\
\hline \multirow{3}{*}{35} & $01 / 09 / 2017$ & 2,54 \\
\cline { 2 - 3 } & $02 / 09 / 2017$ & 1,79 \\
\hline \multirow{4}{*}{36} & $03 / 09 / 2017$ & 4,63 \\
\cline { 2 - 3 } & $04 / 09 / 2017$ & 1,97 \\
\cline { 2 - 3 } & $05 / 09 / 2017$ & 0,54 \\
\cline { 2 - 3 } & $06 / 09 / 2017$ & 0,72 \\
\cline { 2 - 3 } & $07 / 09 / 2017$ & 7,80 \\
\cline { 2 - 3 } & $08 / 09 / 2017$ & 0,73 \\
\hline \multirow{7}{*}{37} & $09 / 09 / 2017$ & 5,46 \\
\cline { 2 - 3 } & $10 / 09 / 2017$ & 2,01 \\
\cline { 2 - 3 } & $11 / 09 / 2017$ & 1,49 \\
\cline { 2 - 3 } & $12 / 09 / 2017$ & 1,86 \\
\hline
\end{tabular}




\begin{tabular}{|c|c|c|}
\hline ISO Week & Date & KOMPAS SPORT NIGHT \\
\hline & $14 / 09 / 2017$ & 8,37 \\
\hline & $15 / 09 / 2017$ & 0,56 \\
\hline & $16 / 09 / 2017$ & 1,18 \\
\hline \multirow{7}{*}{38} & $17 / 09 / 2017$ & 1,90 \\
\hline & $18 / 09 / 2017$ & 2,20 \\
\hline & $19 / 09 / 2017$ & 1,29 \\
\hline & $20 / 09 / 2017$ & 3,37 \\
\hline & $21 / 09 / 2017$ & 2,60 \\
\hline & $22 / 09 / 2017$ & 0,99 \\
\hline & $23 / 09 / 2017$ & 3,86 \\
\hline \multirow{7}{*}{39} & $24 / 09 / 2017$ & 2,41 \\
\hline & $25 / 09 / 2017$ & 2,41 \\
\hline & $26 / 09 / 2017$ & 1,31 \\
\hline & $27 / 09 / 2017$ & 1,15 \\
\hline & $28 / 09 / 2017$ & 1,87 \\
\hline & $29 / 09 / 2017$ & 0,77 \\
\hline & $30 / 09 / 2017$ & 2,70 \\
\hline \multirow{7}{*}{40} & $01 / 10 / 2017$ & 4,34 \\
\hline & $02 / 10 / 2017$ & 1,32 \\
\hline & $03 / 10 / 2017$ & 0,55 \\
\hline & $04 / 10 / 2017$ & 1,19 \\
\hline & $05 / 10 / 2017$ & 1,09 \\
\hline & $06 / 10 / 2017$ & 1,85 \\
\hline & $07 / 10 / 2017$ & 2,90 \\
\hline \multirow{7}{*}{41} & $08 / 10 / 2017$ & 3,38 \\
\hline & $09 / 10 / 2017$ & 1,54 \\
\hline & $10 / 10 / 2017$ & 1,94 \\
\hline & $11 / 10 / 2017$ & 3,78 \\
\hline & $12 / 10 / 2017$ & 0,66 \\
\hline & $13 / 10 / 2017$ & 0,54 \\
\hline & $14 / 10 / 2017$ & 0,77 \\
\hline \multirow{4}{*}{42} & $15 / 10 / 2017$ & 3,62 \\
\hline & $16 / 10 / 2017$ & 3,64 \\
\hline & $17 / 10 / 2017$ & 2,96 \\
\hline & $18 / 10 / 2017$ & 3,24 \\
\hline
\end{tabular}




\begin{tabular}{|c|c|c|}
\hline ISO Week & Date & KOMPAS SPORT NIGHT \\
\hline \multirow{5}{*}{43} & $22 / 10 / 2017$ & 3,77 \\
\hline & $23 / 10 / 2017$ & 2,13 \\
\hline & $24 / 10 / 2017$ & 2,91 \\
\hline & $25 / 10 / 2017$ & 0,71 \\
\hline & $26 / 10 / 2017$ & 3,52 \\
\hline \multirow[t]{6}{*}{44} & $30 / 10 / 2017$ & 2,21 \\
\hline & $31 / 10 / 2017$ & 1,61 \\
\hline & $01 / 11 / 2017$ & 0,32 \\
\hline & $02 / 11 / 2017$ & 0,52 \\
\hline & $03 / 11 / 2017$ & 1,44 \\
\hline & $04 / 11 / 2017$ & 2,85 \\
\hline \multirow{7}{*}{45} & $05 / 11 / 2017$ & 1,68 \\
\hline & $06 / 11 / 2017$ & 1,38 \\
\hline & $07 / 11 / 2017$ & 2,01 \\
\hline & $08 / 11 / 2017$ & 2,24 \\
\hline & $09 / 11 / 2017$ & 1,37 \\
\hline & $10 / 11 / 2017$ & 0,32 \\
\hline & $11 / 11 / 2017$ & 3,34 \\
\hline \multirow{5}{*}{46} & $12 / 11 / 2017$ & 2,31 \\
\hline & $13 / 11 / 2017$ & 1,19 \\
\hline & $14 / 11 / 2017$ & 1,18 \\
\hline & $17 / 11 / 2017$ & 4,08 \\
\hline & $18 / 11 / 2017$ & 3,81 \\
\hline \multirow{7}{*}{47} & $19 / 11 / 2017$ & 2,97 \\
\hline & $20 / 11 / 2017$ & 0,94 \\
\hline & $21 / 11 / 2017$ & 1,76 \\
\hline & $22 / 11 / 2017$ & 2,45 \\
\hline & $23 / 11 / 2017$ & 1,55 \\
\hline & $24 / 11 / 2017$ & 1,18 \\
\hline & $25 / 11 / 2017$ & 2,17 \\
\hline \multirow{5}{*}{48} & $26 / 11 / 2017$ & 2,85 \\
\hline & $27 / 11 / 2017$ & 6,00 \\
\hline & $28 / 11 / 2017$ & 0,87 \\
\hline & $29 / 11 / 2017$ & 0,68 \\
\hline & $30 / 11 / 2017$ & 1,88 \\
\hline
\end{tabular}




\begin{tabular}{|c|c|c|}
\hline \multirow{4}{*}{ ISO Week } & Date & KOMPAS SPORT NIGHT \\
\hline \multirow{4}{*}{49} & $01 / 12 / 2017$ & 1,43 \\
\cline { 2 - 3 } & $02 / 12 / 2017$ & 3,66 \\
\hline & $03 / 12 / 2017$ & 0,74 \\
\cline { 2 - 3 } & $04 / 12 / 2017$ & 0,99 \\
\cline { 2 - 3 } & $05 / 12 / 2017$ & 6,87 \\
\cline { 2 - 3 } & $06 / 12 / 2017$ & 1,60 \\
\cline { 2 - 3 } & $07 / 12 / 2017$ & 2,68 \\
\cline { 2 - 3 } & $08 / 12 / 2017$ & 2,82 \\
\hline \multirow{3}{*}{ Average Program } & $09 / 12 / 2017$ & 1,80 \\
\hline
\end{tabular}

(source: Nielsen, 2017)

In addition to rating and share, overall, the position of a television station can also be viewed through other variables, such as Socio Economic Status (SES) target audience. Executive Producer of Kompas sport, Ebnubeno explained that in accordance with the positioning of Kompas TV as television news, then the program in Kompas TV also, of course, targeting the same audience. SES Audience of Kompas TV is Upper 15+ with SES AB + Male and Female. With this composition it is clear, our target audience are very segmented. That is who understands and loves sports, especially football. Why are we targeting them? because the nature of the sports program have two options, whether targeting a very segmented audience and led to the share and rating, or approach revenue or income-based blocking and others. This is if in this business theory, they enter the blue ocean, something that is not much played. Kompas TV takes a higher task, and it is implemented in the target market set, ie upper middle class.

In the calculation of television station revenue, Nielsen calculated the gross revenue of television station advertising. Gross revenue is the calculation of advertising based on rate card provided by the television station. While the discount and bonus given to the advertising agency is not counted, because Nielsen only records how the rate card based on the time of day, then multiplied by how many ads enter. Based on TV Ad Revenue by Channel from January to November 2017 which shows the gross advertising revenue of Kompas TV, the sports program which only gets about $10 \%$ slot of the total program duration, successfully contributed significant revenue, which is more than 12 percent of total TV compass revenue. Of course the exact figure can not be mentioned here because of the related company policy.

\section{Product Differentiation}

Product differentiation describes the variety of products that are produced by the media. Every media industry typically seeks to have a high degree of differentiation of the products or services they provide in order to have "monopoly power". The diversity created by the media aims to avoid the direct or head-to-head competition facing media managers in a homogeneous market situation. In addition, the diversity is used as a strategy to deal with heterogeneous markets.

According to Executive Producer of Kompas Sport, the statiun must be acceptable to the market that ultimately revenue. Managing this tv media is different from business as usual. So it must have a clear business plan and good to be able to compete, not to mention Kompas TV. So if like a product, we have to create new market and grab the existing market. Not a follower. Not follow-up, but make the quantum leap itself. Well, Kompas TV is already entering the sixth year this year (September 2017), so in the fourth year there must be a difference again .... That we make, after our flagship programs are successful. There are Rosi, Sapa Indonesia and Aiman. Special sports there is Kompas Sport and House of Badminton. We do a guerrilla strategy to seize the core areas, we do frontal attack to the competitors who happen to present earlier than us. Hence when talking about Sapa Indonesia, Kompas Petang, 
Aiman, Rosi, in sport there are Kompas Sport and House of Badminton and others, we do frontal attack. But remember, when the beginning, we are flanking. That is also the service of our programming. In addition, other divisions also play a very important role. Sales and marketing, CRD and more. Well, it must all be a unity. Remember on this television there is nothing big alone.

\section{Barriers to Entry}

Barriers to the media industry emerged as a consequence of the efforts of each media in developing their products. These barriers include the issue of licensing the establishment of national television, government regulation, norms, huge capital investment and the existence of competition between the TV stations themselves.

In Indonesia, the government has given permission to ten national TV stations. Permission for the establishment of a national TV station itself is held by the Ministry of Communication and Information Republic of Indonesia (KemKominfo RI). While the government regulation in the world of television is currently held by the Indonesian Broadcasting Commission (KPI) which issued the Decision of the Indonesian Broadcasting Commission Number 009 / SK / KPI / 8/2004 on Broadcasting Behavior Guidelines and Broadcast Program Standards (P3SPS).).

Executive Producer of Kompas Sport explained that Kompas TV as one of the new national TV in Indonesia certainly can not be separated from this problem, which certainly impact on its programs. Talk program yes of course can not be released with Kompas Sport one of them. In general, outside of sport, if we talk the norm, news channel or news television like Kompas TV must share it high during a disaster or if there are other big events, such as terrorists. But advertisers may not advertise "buy this product" in the middle of disaster news. Those are the norms that apply. Another example, want to blocking time to quiz pas no major disaster. Of course not ethical. However, if government regulations on violence, such as clashes between certain groups, that new government regulations prohibit. In addition, from the side of regulation, Kompas TV never stopped broadcasting due to the applicable rules related to broadcasting television broadcasting permit at the time. Nevertheless, television stations are still required to be able to provide entertainment and information programs that are full of creation and innovation amidst the obstacles it faces. The enormous capital investment in making an innovative program is also a barrier to entering the market. Moreover, the news television market is indeed very segmented ... "(Executive Producer of Kompas Sport)

\section{Cost Structures}

Cost structure consists of fixed cost and variable cost. The analysis is done by classifying the type and the amount of expenditure to support the media industry. Fixed cost in a TV station is used for purposes such as building rental, telephone, electricity and transmission treatment throughout Indonesia. While the variable cost is the expenditure used TV stations in public relations, promotion and unexpected expenditure in the operation of a television station. Kompas Sport as a TV program also of course can not be separated from this element.

Executive Producer of Kompas Sport said that Kompas Sport cost structure is very healthy. Both fixed cost and variable cost are not burdensome. Why? Yes, because we format the bulletin which is certainly more lower cost than the program with other formats. In addition, the human resources in it are permanent employees, not outsourcing or outside talent that has a special price ... "(Executive Producer of Kompas Sport).

In addition to the cost structure in a television station as a whole, there is also a cost structure in the production program. Fixed cost in the production of a program is a cost that has been planned previously. While the variable cost is for unexpected costs. The amount of cost structure that is needed by tvOne in financing various expenses as media industry, at least can describe how big cost structure a national private television station is in Indonesia.

\section{Vertical Integration}

Vertical integration describes the success of the merger or cooperation of several industries. For example, the cooperation between a production house with a cinema or an agency with a newspaper company. As a national television, Kompas TV also certainly performs this vertical integration to fulfill diversity. More focus Kompas Sport as a program also do this, especially with the agency. In Kompas TV itself said The Executive Producer of Kompas Sport that belonging to Kompas Gramedia Group 
synergize with other business units in KG, especially media business unit and printing. We have Kompas TV, Harian Kompas , kompas.com, tribunnews.com, bolasport.com, Tabloid Ball, Radio Sonora and others. All there is sports content. The advantage we get is cross promotion. If we hold a program, we need a radio partner or newspaper for awareness. As with the Borobudr Run event, all the synergy platforms prompted the event to take place successfully and raise the public's enthusiasm for running. In addition, synergy is certainly related to efficiency. For example, there is great news in certain areas, there happens to be contributor or journalist Daily Kompas there. We can ask the contributor's help or journalists from Kompas Daily to report on Kompas TV or provide reportage. And that we often do, and vice versa. We are not alone, all the major media do it. Synergy is important, even if it can be better in one roof. As will KG with integrated newsroom. For now, the synergy has been done is the placement of one office for several divisions. In addition, we also direct the bundling of products, with benefits through banner-banner programs in some programs. For example, an advertiser putting up his product for an event on Kompas TV can also be put on in other platforms, such as print, radio and internet. ... "(Executive Producer of Kompas Sport)

\section{Market Conduct}

Market conduct is an attempt to see the strategies adopted by each media to win the competition between them. In this section, every medium competes to provide something different than other media. Based on the market structure that has been discussed earlier, the condition of television industry market in Indonesia is oligopoly, because it has characteristics where the resulting product has a tendency to differentiation and homogeneous. Many new programs but many TV stations that mimic other TV programs.

According to The Executive Producer of Kompas Sport, that's the direction of leadership to all departments including sports. We must develop a strategy map to continue to compete and be able to seize the market. With what? With Manage cost and expand revenue. The target components are clear, including engagement with digital, optimizing output across all platforms, reinforcing more creative content in others. So Kompas Sport must come to innovate, both in content and in show. For example, we present main speakers and special sources if there are big events or big issues that are being hot conversations, as well as interactive quizzes. There is a special segmentation related to soccer program, such as Bincang Bola and automotive special segment and others. Host appearance is also specified. Creativity should be enhanced, to be able to capture the audience and eventually be able to stay competitive in this industry ... "(Executive Producer of Kompas Sport).

\section{Pricing Behavior}

Pricing strategy is done to face the market structure of TV industry in Indonesia. In the competition to seize the advertiser, the strategy is through pricing strategy. In the face of the market structure of the television industry in Indonesia, Kompas TV is regarded as a newcomer television station, currently still entering into the third layer of advertising revenue. With target audience of SES $\mathrm{AB}+$, and carrying news channel Kompas TV does have low rate card in television industry in Indonesia. However, the low rate card of Kompas TV is regular.

According to Executive Producer opf Kompas Sport, the pricing behavior of Kompas TV is fairly cheap indeed, but continues to accommodate the increase every year. Formerly only Rp 800 per slot now has become Rp 1.5 million. The average income of Kompas TV tens of billions per month. We can not apologize detail here. Good enough for a new television that takes news segmentation. This is all because it is guaranteed, if I masang on other tv not necessarily I can package like this. Recent TV compasses often lead in breaking news programs, even some of them (advertisers) make deals to get into breaking news programs whenever they happen. So they put an ad in the form of CPRP (Cost Per Rate Point). So also in sports in this case Compass Sport and Live Badminton. For pricing behavior, the info I get, Kompas TV has a rate card a bit cheaper than our main competitors. But that does not mean cheap. Because it is tailored to the market mechanism where ratings and TV news share is currently still quite low.

\section{Product Strategy/Advertising}

Product strategy is the effort of each station to produce a different event format with other TV stations. Included in the product strategy in a TV station is the program strategy. Program strategy is 
the effort of each TV station in developing programs as optimal as possible. The Executive Producer of Kompas Sport said that Kompas TV as a new television station is able to provide a breakthrough by presenting talk shows that are packed more informative and up to date, such as Rosi, Aiman and Sapa Indonesia Malam as other alternative spectacle besides sinetron at prime time airing time. These talk show programs later became one of Kompas TV's strategy in taking action as "market challenger" to Metro TV as first mover news television station in Indonesia. Kompas TV is doing "frontal attack" by putting those programs on Metro TV talk show programs at prime time. After the prime time, it is the turn of the sport to play. Filled by experienced sport-casters, Kompas Sport does not take long to win the hearts of sports news viewers. Packed with dynamic, Kompas Sport also continues to provide news updates, even local coverage has become a kind of barometer of Indonesian sports lovers.

Media is naturally a product of diversity $(\mathrm{Fu}, 2003)$. This diversity or variation occurs to avoid direct competition or head to head faced by media managers in a homogeneous market situation. Kompas TV in this program Kompas Sport product differentiation and dare to compete directly with Metro TV. The existence of this variation, is a strategy of oligopolist market players to compete in meeting the heterogeneous consumer tastes. In other words, diversity arises from the diversity of existing enterprises

Market competition in the media industry also affects the diversity of product content produced. Sometimes even competition and diversity are regarded as irreplaceable parts. Dominick and Pearce (1976) in Fu (2003) suggest a link between the diversity of prime-time programs in the United States with media competition. Although Lin (1995a \& 1995b) research in Fu (2003) showed that media diversity decreased due to the heightened competition between media in the 1980s and 1970s.

While in Indonesia, the diversity of media has begun to emerge in the 1990s. This is evident from BPS data showing that this trend has turned into heterogeneous. In the $1990 \mathrm{~s}, 80 \%$ of Indonesians did not graduate from primary school, and $40 \%$ had different thoughts. So previously homogeneous ones tend to be heterogeneous. The Sports Department of Kompas TV is trying to continue to understand this situation and use its data for program development.

\section{CONCLUSION}

Based on the analysis that has been done, can be taken some conclusions. In the framework of Industrial Organization Model analysis, the market structure facing Kompas TV with its flagship sport program, is very heavy. These conditions are indicated by: First, numbers of players of national private television stations are very crowded and market structure has changed, as many television stations merge. Second, product differentiation is increasingly diverse with the emergence of various new programs, one of them through in-house production. Thirdly, barriers to entry are increasingly stringent with various government regulations through KPI.

Market structure condition is then can be regarded as oligopoly market, because in it there are some interdependence company (interdependence). This means that the profit of each company depends on the actions of the company itself and other companies. The company's behavior in the interdependent oligopoly market led to mergers and acquisitions of several television stations.

Kompas TV as a television station that takes news program can be called news channel / news channel newcomer, is a market challenger in television industry in Indonesia. Kompas TV frontal attack against Metro TV, so content strategy conducted by Kompas TV in this case research object Kompas Sport is as follows; in its product strategy, Kompas TV provides a wide selection of news and sports programs, although the main product at prime time is prime time talk show. Differentiation of products made by Kompas TV successfully succeeded in creating an event program that the targeted audience liked, so it has a high degree of monopoly. It certainly affects the price strategy made by Kompas TV. While the promotion strategy by Kompas TV is to maximize the space on the television screen with the assumption that the television itself is the most effective place in the promotion, besides of course by continuing to improve its engagement with other platforms, especially digital. Especially for Kompas Sport, ask specifically for microsite on Kompas TV web, that is kompas.tv/live.

As a benchmark of the success of Kompas TV in facing market competition of television news industry in Indonesia, described through market performance of Kompas TV in this case Kompas Sport program. First, product efficiency, Kompas Sport are both able to do a very large product efficiency because it can create their own events using existing resources. Second, allocative efficiency, Kompas 
Sport is very strict in the efficiency of its resources. Kompas Sport is accustomed to the emphasis of cost.

\section{ACKNOWLEDGMENTS}

This research was supported by Bina Nusantara University. We would like to thank to our colleagues in Community Development Department Bina Nusantara University for their comments on an earlier version of the manuscript. We are also immensely grateful to all informants from Kompas Sport who provided insight and expertise that greatly assisted this research.

\section{REFERENCES}

Albarran, Alan B. (2010). The Media Economy. New York: Rouledge.

Bungin, B. (2011). Penelitian Kualitatif: Komunikasi, Ekonomi, Kebijakan Publik dan Ilmu Sosial Lainnya. Jakarta: Prenada Media Group.

Cabral, L.M.B. (2017). Introduction to Industrial Organization ( $2^{\text {nd }}$ ed). Cambridge, MA: MIT Press.

Chan-Olmsted, S.M. (2006). Handbook of Media Management and Economics. Alan B. Albarran (Ed.). New Jersey: Lawrence Erlbaum Associates Publisher.

$\mathrm{Fu}$, W.W. (2003). Multimarket contact of US newspaper chains: Circulation competition and market coordination. Information Economics and Policy 15 (4). p. 501 -519

Hoskin, C., McFadyen, S. and Finn, A. (2004). Media Economics: Applying Economics to New and Traditional Media. California: Sage Publications.

https://www.scribd.com/doc/43399264/Kep-KPI-009-2004-Pedoman-Perilaku-Penyiaran

Kotler, P. \& Keller, K.L. (2016). Marketing Management, (15 ${ }^{\text {th }}$, global ed). Essex: Pearson Education Limited.

Kompas TV. (2017). About Us [Data File]. Diakses dari https://www.kompas.tv/about-us

Nielsen Audience Measurement. (2017). Laporan Periodik Nielsen Kepada Kompas TV. Jakarta : Kompas TV. 